\title{
STUDI LAJU UMPAN PADA PROSES BIOKONVERSI LIMBAH PENGOLAHAN TUNA MENGGUNAKAN LARVA Hermetia illucens
}

\section{Feeding Rates Study on the Bioconversion of Tuna Processing Waste using Hermetia illucens Larvae}

\author{
Arif Rahman Hakim ${ }^{1 *}$, Agus Prasetya ${ }^{2}$, dan Himawan T. B. M. Petrus ${ }^{2}$ \\ ${ }^{1}$ Loka Riset Mekanisasi Pengolahan Hasil Perikanan, Jl. Imogiri Barat km 11.5 Jetis, Bantul, Indonesia \\ ${ }^{2}$ Departemen Teknik Kimia, Fakultas Teknik, Universitas Gadjah Mada, Jalan Grafika No. 2, Yogyakarta, Indonesia \\ * Korespondensi Penulis: arifrahmanh11@gmail.com
}

Diterima: 27 Juli 2017; Direvisi: 18 September 2017; Disetujui: 22 Desember 2017

\begin{abstract}
ABSTRAK
Seiring dengan berkembangnya industri tuna, limbah pengolahan yang dihasilkan semakin meningkat. Namun demikian pemanfaatan limbah tersebut belum optimal. Biokonversi bahan organik limbah tuna menjadi biomassa larva sebagai bahan pakan diharapkan mampu mengatasi permasalahan tersebut. Biokonversi menggunakan larva Hermetia illucens atau Black Soldier Fly (BSF) memiliki keunggulan dibandingkan proses konversi lain; di antaranya larva BSF mampu mengkonversi berbagai macam bahan organik, memiliki kandungan nutrisi tinggi serta bukan vektor penyakit. Tujuan penelitian ini ialah mempelajari laju umpan larva BSF dalam mengkonversi limbah tuna menjadi biomassa larva. Limbah tuna yang digunakan sebagai umpan larva BSF adalah kepala dan jeroan. Larva dipelihara selama 19 hari dengan pemberian umpan bervariasi (60, 80, $100 \mathrm{mg} / \mathrm{larva} / \mathrm{hari})$. Analisa dilakukan terhadap konsumsi umpan, indeks pengurangan limbah (waste reduction index/WRI), efisiensi konversi umpan tercerna (efficiency of conversion of digested-feed/ECD), tingkat kelulusan hidup (survival rates /SR), bobot larva, kandungan protein dan lemak larva. Hasil penelitian menunjukkan kepala dan jeroan tuna dapat digunakan sebagai pakan BSF, dengan nilai SR 41,33 - 98,33\%. Laju umpan yang menghasilkan proses biokonversi paling optimum adalah umpan berupa kepala tuna sebesar $60 \mathrm{mg} / \mathrm{larva} / \mathrm{hari}(\mathrm{K} 60)$. Nilai parameter pada perlakuan K60 adalah konsumsi umpan 77,09 \%, WRI 4,06 \% per hari, ECD 8,32 \%, bobot larva 72,59 mg dan SR 98,33\%. Limbah berupa kepala tuna menghasilkan konsumsi umpan, WRI, ECD, bobot larva dan SR yang lebih tinggi dibandingkan limbah jeroan tuna. Penggunaan limbah kepala tuna dapat dimanfaatkan untuk mereduksi limbah sekaligus menghasilkan bahan pakan yang potensial. Kandungan larva BSF dengan umpan kepala tuna $60 \mathrm{mg} / \mathrm{larva} / \mathrm{hari}$ meliputi protein $25,38 \%$, lemak $6,85 \%$ dan air $62,81 \%$.
\end{abstract}

KATA KUNCI : Hermetia illucens, limbah pengolahan tuna, biokonversi, laju umpan

\section{ABSTRACT}

Along with the rising of tuna industries, the processing waste is increasing. However, the utilization of this waste has not optimal yet. Bioconversion of organic matters from waste into larvae biomass as feed is expected to overcome the problems. Bioconversion using Hermetia illucens or Black Soldier Fly (BSF) larvae has many advantages over other conversion processes; such as the ability of BSF larvae to convert various organic materials, high nutritional content and not a disease vector. The aim of this study was to determine the optimal feed rate of BSF larvae in converting tuna waste to larvae biomass. Tuna wastes used as feed of BSF larvae were head and viscera. The larvae were cultivated for 19 days with varied feeding rates (60,80, $100 \mathrm{mg} / \mathrm{larva} /$ day). The analyzes were performed on feed consumption, waste reduction index (WRI), efficiency of conversion of digested-feed (ECD), survival rate (SR), larvae weight, larvae protein and its fat. The results showed that head and viscera can be used as BSF feed, with SR $41.33-98.33 \%$. The feeding rate that produce most optimum bioconversion process was 60 (mg/larvae/day) of tuna head (K60). The K60 treatment showed the substrate conpsumtion value of $77,09 \%$, WRI $4,06 \%$ per day, ECD $8,32 \%$, larvae weight $72,59 \mathrm{mg}$ and $S R$ 98,33\%. Tuna head waste produced substrate consumption, $W R I, E C D$, larvae weight and SR higher than waste of tuna viscera. The use of tuna head waste can be utilized to reduce waste as well as to produce potential feed ingredients. The content of BSF larvae fed by $60 \mathrm{mg}$ tuna head/larvae/day were $25,38 \%$ of protein, $6.85 \%$ of fat and $62,81 \%$ of moisture.

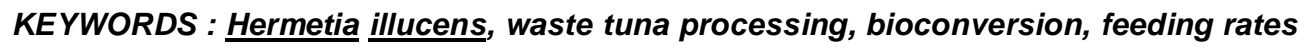

Copyright @ ( 2017, JPBKP, Nomor Akreditasi : 769/AU3/P2MI-LIPI/08/2017

DOI : http://dx.doi.org/10.15578/jpbkp.v12i2.469 


\section{PENDAHULUAN}

Seiring dengan pertumbuhan industri pengolahan hasil perikanan tentu akan diikuti oleh peningkatan limbah yang dihasilkan. Peranginangin, Agusman dan Poernomo, (2011), menyebutkan isu lingkungan yang menjadi perhatian dunia ialah tuntutan pengelolaan hasil perikanan ke arah green production. Hal ini bisa diartikan bahwa perlu adanya optimalisasi pemanfaatan ikan menjadi sesuatu yang bernilai tambah dan menekan limbah yang dihasilkan dengan mengolah menjadi produk bermanfaat. Menurut Retnowati (2011), sisa hasil pengolahan tuna diperkirakan mencapai 716.531 ton dari total produksi bersih unit pengolahan ikan (UPI) sebesar 3.876.796 ton atau sekitar $18,5 \%$. Pengolahan ikan yang menghasilkan sisa paling banyak ialah filet dan pengalengan. Porsi bagian ikan yang terbuang pada proses pengolahan filet yaitu kepala $(20 \%)$, isi perut $(13 \%)$, tulang $(9 \%)$, kulit $(6 \%)$ dan lainnya $(2 \%)$ tergantung jenis ikan (Ghaly, Ramakrishnan, Brooks, Budge, \& Dave, 2013; Trilaksani, 2011).

Disisi lain, pertumbuhan perikanan budidaya tidak diimbangi dengan pertumbuhan pengolahan pakan nasional, sementara biaya terbesar usaha budidaya ialah pada biaya pakan yang bisa mencapai $60-70 \%$ dari total biaya produksi (Widodo \& Fakhri, 2015). Akibatnya, kebutuhan bahan pakan ikan dicukupi dengan jalan impor. Kajian Bappenas (2014) menyatakan dampak dari impor pakan ikan menyebabkan biaya produksi meningkat sehingga membutuhkan modal usaha yang lebih besar, keuntungan pembudidaya berkurang dan usaha budidaya ikan skala kecil akan mengalami degradasi hingga menuju kebangkrutan.

Salah satu alternatif peningkatan ketersediaan bahan pakan secara mandiri adalah memanfaatkan sisa bagian ikan yang terbuang dari industri pengolahan ikan menjadi sumber protein untuk bahan pakan ikan melalui proses biokonversi. Newton, Sheppard, Watson, Burtle, dan Dove (2005) menjelaskan dalam proses biokonversi ini limbah organik akan dikonversi menjadi senyawa sederhana baik protein maupun lemak, melalui proses perubahan yang melibatkan organisme hidup. Proses ini biasanya dikenal sebagai penguraian secara anaerob. Umumnya organisme yang berperan dalam proses biokonversi ini adalah bakteri, jamur dan larva serangga (Chaliforidae, Mucidae, Stratiomydae). Pada limbah hewani, agen perombak yang sering ditemukan adalah larva serangga Diptera dari famili Challifora dan Stratiomydae seperti Hermetia illucens atau Black Soldier Fly (BSF) (Fahmi, Hem, \& Subamia, 2009).

Telah banyak penelitian (Diener, Zurbrügg, \& Tockner, 2009; Fahmi, 2015; Li et al., 2016; Rachmawati, Buchori, Hidayat, Hem, \& Fahmi, 2010; Saragi \& Bagastyo, 2015; Zheng, Li, Zhang, \& Yu,
2012) yang menyatakan bahwa larva BSF memberikan banyak kelebihan dalam mereduksi limbah organik dan berguna sebagai bahan pakan ikan. Larva BSF mampu hidup dan berkembang dalam berbagai media organik karena sifatnya yang memiliki toleransi pH yang luas (Mangunwardoyo, Aulia, \& Hem, 2011). Selain itu, beberapa bakteri yang terdapat di dalam saluran pencernaan larva BSF memiliki kemampuan dalam merombak senyawa organik yang dikonsumsinya (Dong, Chen, Huang, \& Feng, 2009; Yu, et al., 2011).

Kandungan nutrisi larva BSF mencapai 45-50\% dan $24-30 \%$ masing-masing untuk protein dan lemak (Fahmi, 2015). Pada awal penelitian, media yang digunakan untuk pertumbuhan BSF ialah bungkil kelapa sawit atau Palm Kernel Mill (PKM) kemudian terus berkembang hingga menggunakan limbah organik sampah industri dan perkotaan (Saragi \& Bagastyo, 2015). Penelitian lain menginformasikan bahwa larva BSF mampu mereduksi 33-58\% kandungan organik pada kotoran sapi dan $50 \%$ pada kotoran ayam (Myers, Tomberlin, Lambert, \& Kattes, 2008; Sheppard, Newton, Thompson, \& Savage, 1994). Sedangkan sampah organik perkotaan mampu dikurangi hingga berkisar 65,5 - 78,9\% tergantung jumlah limbah yang berikan pada larva serta kondisi lingkungan limbah yang diambil (Diener, Solano, Gutiérrez, Zurbrugg, \& Tockner, 2011).

Black Soldier Fly (BSF) merupakan ordo dari Dipterans, family Stratiomyidae, subfamily Hermetiinae, dan genus Hermetia (Wardhana, 2016). Siklus hidup BSF dari telur hingga menjadi lalat dewasa memerlukan waktu sekitar 40-43 hari, tergantung pada keadaan lingkungan dan umpan yang tersedia. BSF dewasa betina meletakkan telurnya di dekat sumber umpan; antara lain pada bongkahan kotoran unggas atau ternak, tumpukan limbah bungkil inti sawit dan limbah organik lainnya. Larva BSF banyak diaplikasikan sebagai pakan ikan ketika memasuki fase pupa atau usia 3-4 minggu. Detail siklus hidup larva BSF tersaji pada Gambar 1.

Penelitian untuk memanfaatkan limbah tuna dari industri pengolahan ikan untuk pakan larva sebagai upaya biokonversi belum dilakukan. Penelitian ini dimaksudkan untuk mempelajari penggunaan limbah tuna dari pengalengan tuna untuk pertumbuhan larva BSF yang selanjutnya dimanfaatkan sebagai bahan baku pakan ikan. Hal ini menjadi dasar pengolahan limbah industri perikanan dengan metode lebih ramah lingkungan. Dari penelitian ini diharapkan dapat diperoleh informasi pengaruh laju umpan berupa kepala dan jeroan tuna terhadap kecepatan penguraiannya oleh larva BSF. Yang dimaksud dengan laju umpan adalah jumlah pakan yang dikonsumsi oleh larva BSF per satuan waktu dengan satuan $\mathrm{mg} / \mathrm{larva} / \mathrm{hari}$. 


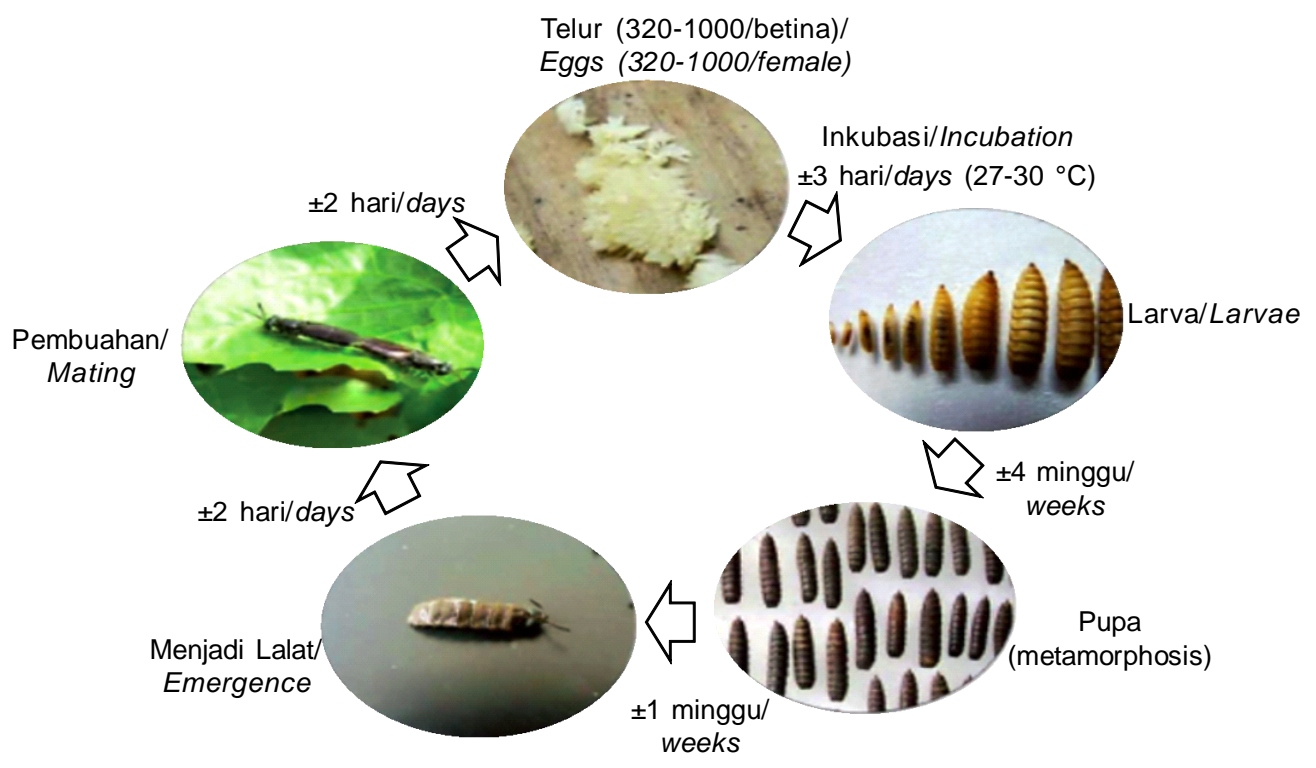

Gambar 1. Siklus hidup BSF (Sumber: Caruso, Devic, Subamia, Talamond, \& Baras, 2014)

Figure 1. BSF life cycle (Source : Caruso, Devic, Subamia, Talamond, \& Baras, 2014)

\section{BAHAN DAN METODE}

\section{Bahan}

Bahan utama dalam penelitian ini meliputi limbah pengolahan tuna (kepala dan jeroan) yang diperoleh dari industri pengalengan ikan tuna di Kabupaten Pasuruan Jawa Timur. Limbah yang diperoleh dibawa menggunakan box berpendingin. Limbah dibungkus kantong plastik lalu dimasukkan ke dalam box kemudian ditambahkan es curai. Telur BSF diperoleh dari Balai Riset Budidaya Ikan Hias Kementerian Kelautan dan Perikanan yang berlokasi di Kota Depok, Jawa Barat. Media penetasan telur BSF berupa dedak $(0,5 \mathrm{~kg})$, wortel $(0,5 \mathrm{~kg})$, kacang panjang $(0,5$ $\mathrm{kg})$, sawi $(0,25 \mathrm{~kg})$ dan $\mathrm{kol}(0,25)$ yang diperoleh dari pasar lokal di Kabupaten Bantul. Alat yang digunakan dalam penelitian ini berupa peralatan pemeliharaan larva BSF yang berupa kontainer plastik dengan ukuran $14 \mathrm{~cm} \times 7,5 \mathrm{~cm} \times 7 \mathrm{~cm}$ dan kain penutup.

\section{Metode}

Pada penelitian ini, laju umpan dihitung dengan cara memberikan umpan dengan jumlah tertentu $(\mathrm{mg})$ ke larva selama waktu tertentu (hari) kemudian selisih jumlah awal dan jumlah umpan sisa dianggap sebagai nilai laju umpan. Semakin tinggi laju umpan menunjukkan tingginya kecepatan larva dalam mengkonsumsi umpan yang diberikan. Artinya nilai pengurangan limbah akan semakin baik pula. Umpan pada penelitian ini merupakan pakan sekaligus media hidup larva BSF.
Langkah pertama adalah penyiapan media untuk penetasan telur BSF. Media tetas berupa campuran dedak $(0,5 \mathrm{~kg})$ dan sayuran wortel $(0,5 \mathrm{~kg})$, kacang panjang $(0,5 \mathrm{~kg})$, sawi $(0,25 \mathrm{~kg})$, dan $\mathrm{kol}(0,25 \mathrm{~kg})$. Selanjutnya telur diletakkan pada permukaan media tersebut pada suhu ruang di dalam kontainer plastik/ ember. Telur menetas dalam waktu 2-3 hari. Larva yang diperoleh dikultivasi selama 6 hari. Larva tersebut kemudian dijadikan agen biokonversi limbah pengolahan tuna. Selama proses kultivasi larva, dipersiapan juga bahan yang akan dikonversi atau umpan larva. Umpan tersebut berupa 2 jenis limbah pengolahan tuna yaitu kepala dan jeroan masingmasing sebagai perlakuan yang berbeda.

Limbah tuna diperoleh dari pabrik pengalengan tuna. Limbah dibawa ke tempat penelitian dalam kondisi dingin $\left(0-5^{\circ} \mathrm{C}\right)$ dengan es curai. Setelah di laboratorium, limbah (kepala dan jeroan) dicuci bersih dengan air tawar dan dilakukan pengecilan ukuran atau pemotongan hingga ukuran 1-2 cm. Umpan ini lalu disimpan dalam freezer sampai saatnya digunakan. Sebelum digunakan umpan dibiarkan di udara terbuka sampai suhu ruang. Larva usia 6 hari selanjutnya diberikan perlakuan umpan harian menggunakan kepala dan jeroan yang sudah dipotong-potong selama 19 hari. Larva dimasukkan dalam kontainer plastik lalu diberikan pakan dan ditutup kain anti nyamuk dengan tujuan agar tidak ada serangga atau binatang lain yang masuk. Jumlah larva yang digunakan sebanyak 200 ekor pada setiap perlakuan dan diulang sebanyak 3 kali. Sedangkan variasi laju umpan (kepala dan jeroan) yang diberikan pada larva yaitu $60 \mathrm{mg} /$ 
larva/hari, $80 \mathrm{mg} /$ larva/hari dan $100 \mathrm{mg} /$ larva/hari (Diener et al., 2009; dan Saragi \& Bagastyo, 2015).

\section{Pengamatan}

Pengamatan dilakukan terhadap konsumsi umpan, indeks pengurangan limbah, efisiensi konversi umpan tercerna, biomassa larva, tingkat kelulusan hidup dan proksimat.

\section{Konsumsi umpan}

Konsumsi umpan adalah jumlah umpan yang dikonsumsi larva yang dinyatakan dalam persen selama masa pemeliharaan. Untuk menghitung konsumsi umpan, sisa umpan yang diberikan pada larva setelah 3 hari ditimbang lalu dibandingkan dengan berat umpan pada awal perlakuan (Diener et al., 2009). Penimbangan sisa umpan dilakukan setiap 3 hari untuk mengurangi tingkat stres pada larva akibat pergantian umpan dan penimbangan sisa umpan.

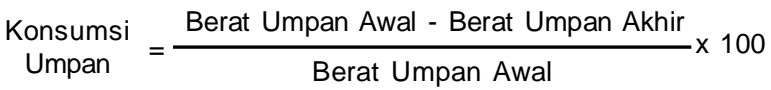

\section{Indeks pengurangan limbah (waste reduction index/WRI)}

Indeks pengurangan limbah (waste reduction index/ WRI) adalah indeks pengurangan limbah (kepala dan jeroan tuna) oleh larva per hari. Nilai WRI yang tinggi memberi makna kemampuan larva dalam mereduksi umpan yang tinggi pula. Nilai pengurangan umpan dihitung berdasarkan persamaan yang dikemukakan Diener et al. (2009) yaitu:

$$
\begin{aligned}
& W R I=\frac{D}{t} \times 100 \\
& D=\frac{W-R}{W}
\end{aligned}
$$

Keterangan:

W : jumlah umpan total $(\mathrm{mg})$

t : total waktu larva memakan umpan (hari)

$\mathrm{R}$ : sisa umpan total setelah waktu tertentu $(\mathrm{mg})$

D : penurunan umpan total

WRI: indeks pengurangan limbah (Waste reduction index)

\section{Efisiensi konversi umpan tercerna (Efficiency of conversion of digested feed/ECD)}

Efisiensi konversi umpan tercerna atau efficiency of conversion of digested feed (ECD) adalah efisiensi konversi umpan yang dicerna oleh larva selama masa pemeliharaan. Perhitungan berdasarkan metode Scriber dan Slansky (1981) yaitu:

$$
E C D=\frac{B}{(I-F)}
$$

Keterangan:

ECD : efficiency of conversion of digested feed (efisiensi konversi umpan tercerna)

B : pertambahan berat larva selama periode makan; diperoleh dari pengurangan berat akhir larva dengan berat awal larva (mg).

I : jumlah umpan yang dikonsumsi; diperoleh dari pengurangan berat awal pakan dengan berat akhir pakan $(\mathrm{mg})$

f $\quad$ : berat sisa umpan dan material hasil ekskresi (mg)

\section{Biomassa larva}

Biomassa larva adalah bobot atau berat larva (mg). Pengukuran berat larva BSF dilakukan setiap hari dan dicatat dalam jurnal pemantauan berat larva. Hasil dari pengukuran berat larva ditotal dan dibagi dengan jumlah larva yang diukur untuk mencari berat ratarata larva setiap 3 hari (Diener et al., 2009).

$$
\text { Berat rata-rata }=\frac{\text { Total berat larva }}{\text { Jumlah total larva }}
$$

\section{Tingkat kelulusan hidup (survival rate)}

Tingkat kelulusan hidup (survival rates) merupakan jumlah larva yang hidup dibandingkan dengan jumlah awal larva, dihitung dalam satuan persen (Myers et al., 2008).

$$
\text { Survival Rate }=\frac{\begin{array}{c}
\text { Jumlah larva hidup akhir } \\
\text { pemeliharaan }
\end{array}}{\begin{array}{c}
\text { Jumlah larva hidup awal } \\
\text { pemeliharaan }
\end{array}} \times 100
$$

\section{Proksimat}

Analisa proksimat dilakukan terhadap larva dan umpan larva. Uji proksimat meliputi kadar protein, kadar lemak dan kadar air (AOAC, 2006).

\section{Analisa statistik}

Data yang diperoleh selanjutnya dianalisa secara statistik menggunakan software Minitab versi 17. Uji lanjut menggunakan Tukey dengan tingkat kepercayaan 95\%. 


\section{HASIL DAN BAHASAN}

\section{Proksimat Umpan dan Larva}

Hasil analisa proksimat pada umpan yang digunakan berupa limbah kepala dan jeroan tuna bisa dilihat pada Tabel 1.

Data pada Tabel 1. menunjukkan bahwa kandungan air dan lemak pada jeroan tuna lebih tinggi dibandingkan pada kepala tuna, namun kandungan proteinnya lebih rendah. Pada penelitian lain (Kantun, Mallawa, \& Rapi, 2014) disebutkan bahwa kepala tuna mengandung air $78,34 \%$, protein $16,41 \%$, dan lemak $1,66 \%$. Sedangkan jeroan atau isi perut tuna mengandung kadar air $75,42 \%$, kadar protein $17,11 \%$, dan kadar lemak 1,63\% (Riyanto, Uju, \& Halimi, 2012). Kandungan protein pada kepala dan jeroan yang digunakan dalam penelitian ini lebih tinggi dibanding beberapa penelitian sebelumnya. Hal ini kemungkinan disebabkan karena perbedaan musim dan lokasi perairan ikan tuna tersebut ditangkap. Kandungan protein dipengaruhi oleh faktor makanan, musim, pergerakan ikan, lingkungan, suhu dan umur ikan (Kantun et al., 2014).

Bardasarkan komposisi bahan yang terkandung dalam limbah tersebut, maka limbah kepala dan jeroan merupakan bahan organik yang bisa dimanfaatkan oleh larva BSF sebagai umpan. Hal ini didukung oleh penelitian sebelumnya (Diener et al., 2009; Driemeyer, 2016; Fahmi, 2015; Myers et al.,
2008; Saragi \& Bagastyo, 2015) yang menggunakan media organik dengan komposisi dominan (protein, lemak dan air) yang serupa dengan komposisi limbah kepala dan jeroan tuna (Tabel 1).

Larva BSF mampu hidup dan berkembang dalam berbagai media organik karena sifatnya yang memiliki toleransi pH yang luas (Mangunwardoyo et al., 2011). Selain itu, beberapa bakteri yang terdapat di dalam saluran pencernaan larva BSF memiliki kemampuan dalam merombak senyawa organik yang dikonsumsinya (Dong et al., 2009; Yu et al., 2011).

Selanjutnya larva yang telah berumur 6 hari dipindahkan ke wadah pemeliharaan yang berisi limbah tuna (kepala dan jeroan) dengan variasi laju umpan 60, 80 dan $100 \mathrm{mg} / \mathrm{larva} / \mathrm{hari}$ dan dianalisa proksimat biomassa larvanya setelah panen (hari ke-19). Hasil analisa proksimat meliputi protein, lemak dan air disajikan pada Tabel 2.

Pada proksimat biomassa larva setelah pemeliharaan 19 hari terjadi kenaikan kadar protein dan lemak, namun terjadi penurun kadar air. Kadar protein berkisar $22,24-28,73 \%$, tertinggi pada laju umpan jeroan tuna sebanyak $80 \mathrm{mg} / \mathrm{larva} /$ hari yaitu $28,7 \%$ diikuti oleh perlakuan laju umpan kepala 60 $\mathrm{mg} / \mathrm{larva}$ /hari yaitu $25,38 \%$. Sedangkan nilai protein terendah yaitu $22,24 \%$ terjadi pada perlakuan laju umpan kepala $80 \mathrm{mg} / \mathrm{larva} / \mathrm{hari}$. Umpan yang diberikan pada larva memiliki nilai protein sebesar $23,43-$ $25,58 \%$. Data ini menunjukkan bahwa larva BSF

Tabel 1. Hasil analisa proksimat limbah tuna

Tabel 1. Result of proximate analysis of tuna waste

\begin{tabular}{lcc}
\hline \multicolumn{1}{c}{ Parameter/Parameters } & Kepala/Head & Jeroan/Viscera \\
\hline Kadar air/Moisture $(\%)$ & $66.98 \pm 2.37$ & $73.10 \pm 0.75$ \\
Protein/Protein $(\%)$ & $25.58 \pm 2.11$ & $23.43 \pm 3.12$ \\
Lemak/Fat $(\%)$ & $0.85 \pm 0.14$ & $2.64 \pm 1.10$ \\
\hline
\end{tabular}

Tabel 2. Komposisi proksimat larva BSF sebelum dan setelah 19 hari pemberian pakan kepala dan jeroan tuna Table 2. Proximate composition of BSF larvae before and after 19 days fed with tuna head and veiscera

\begin{tabular}{|c|c|c|c|c|c|c|c|}
\hline \multirow{3}{*}{$\begin{array}{c}\text { Proksimat/ } \\
\text { Proximates } \\
\text { (\%) }\end{array}$} & \multirow{3}{*}{$\begin{array}{l}\text { Awal/ } \\
\text { Initial } \\
\text { larva }\end{array}$} & \multicolumn{6}{|c|}{ Setelah 19 hari pemberian umpan lim bah tuna/After 19 days fed with tuna waste } \\
\hline & & \multicolumn{2}{|c|}{$\begin{array}{l}\text { Laju um pan } 60 \mathrm{mg} / \mathrm{hari} / \\
\text { feeding rate } 60 \mathrm{mg} / \text { day }\end{array}$} & \multicolumn{2}{|c|}{$\begin{array}{l}\text { Laju um pan } 80 \mathrm{mg} / \mathrm{hari} / \\
\text { feeding rate } 80 \mathrm{mg} / \text { day }\end{array}$} & \multicolumn{2}{|c|}{$\begin{array}{l}\text { Laju um pan } 100 \mathrm{mg} / \mathrm{hari} / \\
\text { feeding rate } 100 \mathrm{mg} / \text { day }\end{array}$} \\
\hline & & Kepala/head & Jeroan/viscera & Kepala/head & Jeroan/viscera & Kepala/head & Jeroan/viscera \\
\hline Protein/Protein & $0.4 \pm 0.1$ & $25.3 \pm 3.2^{a}$ & $23.1 \pm 1.5^{a}$ & $22.2 \pm 2.2^{\mathrm{a}}$ & $28.7 \pm 3.3^{a}$ & $22.7 \pm 0.8^{a}$ & $22.9 \pm 2.2^{a}$ \\
\hline Lemak/Fat & $0.7 \pm 0.02$ & $6.8 \pm 1.9^{a}$ & $9.6 \pm 1.2^{\mathrm{a}}$ & $6.1 \pm 1.2^{\mathrm{a}}$ & $9.8 \pm 2.7^{a}$ & $8.8 \pm 1.8^{\mathrm{a}}$ & $8.2 \pm 1.5^{a}$ \\
\hline Air /Moisture & $74.0 \pm 2.4$ & $62.8 \pm 6.9^{a}$ & $63.4 \pm 6.9^{a}$ & $64.1 \pm 3.5^{a}$ & $60.6 \pm 7.6^{a}$ & $63.8 \pm 6.5^{a}$ & $60.5 \pm 3.9^{a}$ \\
\hline
\end{tabular}

$a=$ Notasi huruf yang sama dalam baris yang sama menunjukkan perbedaan nilai tidak signifikan $(p \geq 0,05) /$ The same letters notation within a row shows no significant difference $(p \geq 0.05)$ 
mampu menyerap protein yang ada dalam umpan dengan baik bahkan pada perlakuan laju umpan berupa jeroan $80 \mathrm{mg} /$ hari kadar protein di dalam biomassa larva bisa meningkat.

Kondisi hampir sama terjadi pada kadar lemak. Pada awal pemeliharaan rata-rata kadar lemak larva hanya sebesar 0,66 \% lalu meningkat setelah diberikan umpan berupa limbah tuna selama 19 hari menjadi $6,12-9,8 \%$. Larva dengan umpan jeroan tuna memiliki rata-rata kadar lemak yang lebih tinggi dibandingkan larva dengan umpan kepala tuna. Hal ini terjadi karena kadar lemak dalam jeroan tuna lebih tinggi dibandingkan kepala tuna. Sedangkan perbedaan laju umpan yang diberikan (60, 80 dan 100 $\mathrm{mg} /$ larva/hari) tidak memberikan pola tertentu (naik/ turun) pada kadar protein dan lemak. Hasil analisa statistik memberikan nilai perbedaan yang tidak signifikan ( $p>0,05)$.

Kemampuan larva BSF untuk memakan berbagai jenis bahan organik kemudian merubahnya menjadi protein, lemak maupun kalori adalah karena keberadaan enzim protease, lipase dan amilase dalam sistem pencernaannya (Kim et al., 2011). Dengan demikian biomassa larva akan memiliki kandungan nutrisi yang kurang lebih sama dengan kandungan nutrisi pakan yang diberikan. Perbandingan nilai proksimat larva pada larva BSF yang diberikan umpan dari berbagai jenis limbah organik bisa dilihat pada Tabel 3.

Nilai protein larva dalam penelitian ini lebih tinggi dibandingkan dengan nilai protein larva pada penelitian Nguyen, Tomberlin, dan Vanlaerhoven (2015) dan juga penelitian Hartoto (2011). Perbedaan nutrisi pada umpan akan menyebabkan kandungan nutrisi pada larva berbeda-beda. Tomberlin, Sheppard, dan Joyce (2002), mengemukakan bahwa nutrisi larva BSF sangat dipengaruhi oleh media tempat mereka berkembang biak. Bila media tersebut kaya protein maka larva akan mengandung tinggi protein, demikian pula bila media kaya akan lemak maupun serat. Demikian juga hasil penelitian Tschirner dan Simon
(2015), yang menyebutkan kandungan nutrisi larva BSF ditentukan oleh umpan yang dikonsumsi. Larva BSF mampu merubah protein dan lemak menjadi sumber energi sebaik pada konversi energi dari karbohidrat (Diener et al., 2009).

\section{Parameter Fisik Larva BSF}

Parameter selanjutnya yang diamati pada penelitian ini ialah parameter fisik larva BSF yang meliputi nilai konsumsi umpan, indeks pengurangan limbah, efisiensi umpan tercerna, bobot larva dan kelulusan hidup. Perbandingan nilai hasil pengamatan parameter fisik pada penelitian ini tersaji pada Tabel 4.

\section{Konsumsi Umpan}

Pemberian umpan kepada larva BSF berupa kepala ikan dan jeroan sebesar 60, 80 dan 100 mg/larva/hari menghasilkan nilai konsumsi umpan sebagai pakan sebesar 52,33-77,09\% (Tabel 4). Nilai tertinggi pada pemberian umpan berupa kepala $60 \mathrm{mg}$ dengan nilai $77,09 \%$ dan terendah pada pemberian umpan berupa jeroan $100 \mathrm{mg}$ dengan nilai 52,33\%. Umpan yang dikonsumsi cenderung menurun dengan meningkatnya jumlah umpan yang diberikan kepada larva, baik umpan berupa kepala maupun jeroan ikan. Hasil analisa statistik menunjukkan bahwa perlakuan perbedaan laju umpan dan jenis umpan memberikan pengaruh yang nyata terhadap nilai konsumsi umpan. Berdasarkan nilai tersebut pemberian umpan sebanyak $60 \mathrm{mg} / \mathrm{larva} /$ hari merupakan laju paling optimal untuk pengurangan umpan.

Data pada Tabel 4 menunjukkan bahwa semakin tinggi nilai konsumsi umpan maka larva mampu mengkonsumsi lebih banyak umpan yang diberikan. Tabel 4 juga membuktikan bahwa larva lebih mudah mereduksi limbah kepala dibandingkan dengan limbah berupa jeroan ikan. Kadar air jeroan yang lebih tinggi (Gambar 2) diduga merupakan salah satu penyebabnya. Penelitian sebelumnya (Bonso, 2013; Diener et al., 2009; Li et al., 2011; Mutafela, 2015; Tran, Gnaedinger, \& Melin, 2014), menyatakan bahwa dalam membudidayakan BSF kadar air media harus

Tabel 3. Komposisi proksimat larva dibandingkan penelitian lain

Table 3. Proximate composition of larvae compared to others study

\begin{tabular}{cccc}
\hline $\begin{array}{c}\text { Parameter/ } \\
\text { Parameters }\end{array}$ & $\begin{array}{c}\text { Penelitian ini/This } \\
\text { study (K60) }\end{array}$ & Nguyen et al. (2015) & Hartoto (2011) \\
\hline Pakan/Feed & kepala ikan/Head fish & Ikan/Fish & $\begin{array}{c}\text { Dedak dan sayuran } \\
\text { limbah/Bran and } \\
\text { vegetable waste }\end{array}$ \\
\hline Protein/ protein (\%) & 25.4 & 19.4 & 23.3 \\
Lemak/ fat (\%) & 6.9 & 11.6 & 3.7 \\
Air / Moisture (\%) & 62.8 & 53.4 & 28.1 \\
\hline
\end{tabular}


Tabel 4. Perbandingan nilai parameter pada larva yang diberi umpan limbah kepala $(\mathrm{K})$ dan jeroan $(\mathrm{J})$ Table 4. Comparation of parameter value on larvae fed waste head $(K)$ and viscera $(Y)$

\begin{tabular}{|c|c|c|c|c|c|c|}
\hline \multirow{2}{*}{$\begin{array}{l}\text { Parameter/ } \\
\text { Parameters }\end{array}$} & \multicolumn{6}{|c|}{ Perlakuan/Treatments } \\
\hline & K60 & J60 & K80 & $\mathrm{J} 80$ & K100 & J100 \\
\hline $\begin{array}{l}\text { Konsumsi umpan/Substrate } \\
\text { consumption (\%) }\end{array}$ & $77.09 \pm 1.01^{\mathrm{a}}$ & $62.88 \pm 3.08$ bc & $68.23 \pm 5.59 a b$ & $60.34 \pm 5.06 \mathrm{bc}$ & $64.02 \pm 2.67^{\mathrm{bc}}$ & $52.33 \pm 6.46^{c}$ \\
\hline $\begin{array}{l}\text { Indeks pengurangan limbah } \\
\text { (\% hari)/Waste reduction } \\
\text { index }(\% \text { day) }\end{array}$ & $4.06 \pm 0.05^{\mathrm{a}}$ & $3.31 \pm 0.16^{b c}$ & $3.59 \pm 0.29$ ab & $3.18 \pm 0.27^{b c}$ & $3.37 \pm 0.14 \mathrm{bc}$ & $2.75 \pm 0.34^{c}$ \\
\hline $\begin{array}{l}\text { Efisiensi umpan } \\
\text { tercerna/Efficiency of } \\
\text { Conversion of Digested- } \\
\text { Feed (\%) }\end{array}$ & $8.32 \pm 0.84^{a}$ & $6.72 \pm 1.45^{a b}$ & $7.95 \pm 1.35^{\mathrm{a}}$ & $4.26 \pm 0.85^{b c}$ & $7.6 \pm 0.87^{a}$ & $3.03 \pm 1.06^{c}$ \\
\hline $\begin{array}{l}\text { Bobot larva/Larvae } \\
\text { weight }(\mathrm{mg})\end{array}$ & $72.59 \pm 6.04 \mathrm{ab}$ & $62.62 \pm 11.00^{\mathrm{b}}$ & $82.99 \pm 13.35$ ab & $69.16 \pm 4.84^{b}$ & $95.04 \pm 11.68^{a}$ & $59.38 \pm 4.91^{b}$ \\
\hline $\begin{array}{l}\text { Kelulusan hidup/Survival } \\
\text { rate (\%) }\end{array}$ & $98.33 \pm 4.2^{\text {a }}$ & $64.17 \pm 25.0 \mathrm{bcd}$ & $96 \pm 7.2^{a b}$ & $53.33 \pm 4.5^{\mathrm{cd}}$ & $85.17 \pm 33.3 \mathrm{abc}$ & $41.33 \pm 22.4^{d}$ \\
\hline
\end{tabular}

$a, \bar{b}=$ Notasi huruf yang sama dalam baris yang sama menunjukkan perbedaan nilai tidak signifikan $(p \geq 0,05) /$ The same letters notation within a row shows no significant difference $(p \geq 0.05)$

rendah karena larva tidak dapat berkembang baik bahkan tidak dapat tumbuh (peningkatan bobot) pada media dengan kadar air tinggi, yaitu $>70 \%$. Hal senada disampaikan oleh Saragi dan Bagastyo (2015) bahwa kondisi media tumbuh/pakan/umpan larva dengan kadar air tinggi akan menyebabkan kondisi anaerobik. Proses dekomposisi bahan organik dalam kondisi anaerobik akan menghasilkan $\mathrm{NH}_{3}$ (ammonia) dan $\mathrm{CH}_{4}$ (metana) yang bisa menghambat proses konsumsi umpan oleh larva dan mempengaruhi pertumbuhanya.

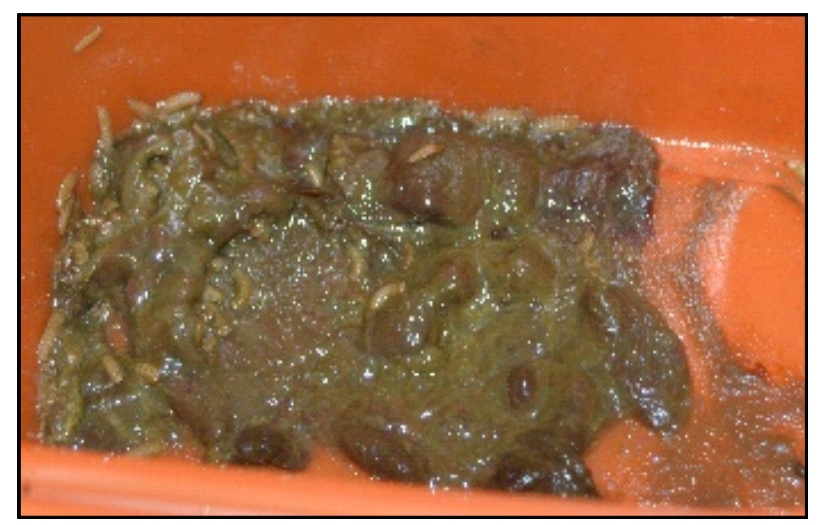

(A)
Nilai konsumsi umpan larva dengan pakan limbah ikan lebih tinggi dibandingkan dengan penelitianpenelitian sebelumnya (Diener et al., 2009; Supriyatna, Manurung, Esyanti, \& Putra, 2016) . Hal ini menunjukkan bahwa semakin tinggi nilai konsumsi umpan maka potensi pemanfaatan larva untuk mengurai pakan atau limbah semakin besar. Penelitian Diener et al. (2009) yang menggunakan pakan ayam sebagai umpan larva BSF memperoleh nilai konsumsi umpan sebesar 26,2 - 39,7\%. Sedangkan pada penelitian Supriyatna et al. (2016) dengan umpan

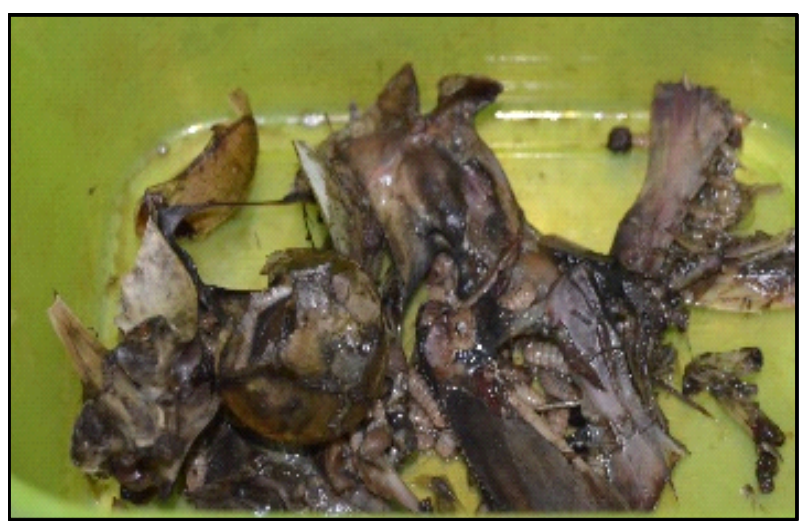

(B)

Gambar 2. Kondisi umpan pada hari kedua (a) jeroan tuna, (b) kepala tuna/ Figure 2. Condition of feed on the second days in tuna (a) viscera, (b) head 
berupa limbah singkong dihasilkan nilai konsumsi umpan sebesar 9,29-36,82\%. Perbedaan nilai ini kemungkinan disebabkan oleh kualitas umpan yang berbeda sehingga berpengaruh terhadap sumbangan zat gizi bagi larva BSF untuk berkembang. Nilai protein limbah ikan lebih lengkap dibandingkan limbah singkong maupun pakan ayam. Menurut Tomberlin et al. (2002), komposisi nutrisi media berpengaruh terhadap tumbuh kembang larva BSF. Umpan dengan kandungan protein dan lemak tinggi akan mempercepat kenaikan bobot larva.

\section{Indeks pengurangan limbah/Waste Reduction Index (WRI)}

Nilai konsumsi umpan selanjutnya digunakan untuk menentukan nilai Waste Reduction Index (WRI) (Diener et al., 2009). Nilai WRI digunakan untuk menghitung kemampuan larva BSF dalam mengkonsumsi umpan dengan mempertimbangkan waktu atau periode pemberian umpan. Nilai WRI yang tinggi memberi makna kemampuan larva dalam mereduksi umpan yang tinggi pula. Nilai WRI pada Tabel 4 memberikan informasi bahwa nilai tertinggi adalah sebesar 4,06 pada perlakuan $\mathrm{K} 60$ dan terendah sebesar 2,75 pada perlakuan J100. Jumlah pakan yang diberikan pada K60 bisa dikonsumsi oleh larva secara optimal dibandingkan perlakuan lain. Nilai WRI ini berbanding lurus dengan nilai konsumsi umpan. Jika nilai konsumsi tinggi maka nilai WRI juga tinggi. Pada perlakuan umpan dengan jumlah lebih tinggi maka nilai WRI cenderung turun. Hal ini dimungkinkan larva sudah tidak mampu lagi mengkonsumsi umpan yang diberikan sebab umpan terlalu banyak sehingga nilai presentase umpan yang dikonsumsi terhadap total umpan menjadi lebih rendah.

\section{Efisiensi konversi pakan tercerna/Efficiency of Conversion Digested-feed (ECD)}

Nilai rata-rata Efficiency of Conversion Digested feed (ECD) pada penelitian ini bervariasi antara 3,03\% $-8,32 \%$ (Tabel 4). Nilai ECD merupakan gambaran tingkat efisiensi larva BSF dalam mengkonversi umpan yang dikonsumsi menjadi biomassanya. Semakin tinggi nilai ECD maka semakin tinggi pula tingkat efisiensinya. Hasil uji statistik menunjukkan bahwa nilai ECD pada pelakuan pemberian umpan kepala ikan tidak berbeda signifikan, namun lebih tinggi serta berbeda nyata bila dibandingkan dengan perlakuan pemberian umpan jeroan ikan.

Rendahnya jumlah umpan jeroan tuna yang dikonsumsi mengakibatkan jumlah umpan yang diubah menjadi biomassa larva BSF menjadi menurun, sehingga nilai ECD menurun. Hal tersebut akan mempengaruhi bobot larva. Simpson dan Simpson (1990) mengungkapkan bahwa larva serangga tidak mungkin menyeleksi makanannya karena tidak tersedianya variasi makanan. Konsekuensi yang muncul adalah kompensasi pada efisiensi konversi umpan yang dimakan cenderung rendah. Sedangkan menurut Timmins, Bellward, Stamp dan Reynolds (1988) dan Ahmad (2001), rendahnya nilai ECD pada pertumbuhan larva serangga berhubungan dengan kualitas umpan yang tersedia. Kualitas umpan yang kurang bagus akan memberikan nilai ECD lebih rendah. Penjelasan ini menunjukkan bahwa kualitas nutrisi jeroan ikan lebih rendah dibandingkan nutrisi pada kepala tuna (Tabel 1).

Menurut Affiano (2011), bagian perut ikan tuna merupakan bagian yang paling rentan terhadap penurunan mutu karena jumlah bakteri di dalam isi perut yang ada di bagian perut tersebut paling banyak dibandingkan bagian lain. Selain itu kandungan histamin pada jeroan tuna cukup tinggi yaitu 19,38 ppm (Nurhayati, Salamah, Cholifah, \& Nugraha, 2014). Hal ini diduga ikut mempengaruhi kualitas jeroan sebagai umpan larva BSF. Akibatnya ECD dan peningkatan bobot larva rendah.

\section{Bobot larva}

Larva dalam penelitian ini dipelihara hingga usia 19 hari. Bobot dihitung secara berkala setiap 3 hari. Hasil pengamatan bobot larva mulai hari ke-1 hingga hari ke-19 tersaji pada Gambar 3. Rata-rata bobot awal larva (usia 6 hari) adalah 2,4 mg. Pada Gambar 3 tersebut terlihat bahwa bobot larva mulai mengalami perbedaan pada hari ke-4. Bobot larva terus bertambah dengan bertambahnya masa pemeliharaan.

Perbedaan bobot larva terjadi hingga masa pemeliharaan diakhiri yaitu hari ke-19. Detail bobot akhir larva bisa dilihat pada Tabel 4. Bobot tertinggi pada perlakuan K100 yaitu 95,04 mg/larva dan terendah pada perlakuan J100 yaitu $59,38 \mathrm{mg} / \mathrm{larva}$. Berdasarkan analisa statistik, perlakuan K100 tidak berbeda nyata dengan perlakuan $\mathrm{K} 60$ dan K80 meskipun perbedaan nilai cukup besar $(>30 \%)$, tetapi karena deviasi cukup tinggi perbedaan sebesar itu tetap tidak signifikan. Sedangkan bila dibandingkan dengan perlakuan J60, J80 dan $\mathrm{J} 100$ maka nilai bobot larva berbeda signifikan.

Larva dengan umpan kepala ikan menghasilkan bobot yang lebih berat dibandingkan dengan pemberian umpan berupa jeroan. Hal ini dimungkinkan karena kadar air pada jeroan $(73,10 \% \pm 0,75)$ yang lebih tinggi dibandingkan kadar air kepala ikan $(65,62$ $\pm 0,42 \%$ ) sehingga menyebabkan terganggunya proses konsumsi umpan oleh larva. Larva BSF tidak menyukai umpan dengan kadar air tinggi dan akan mencari tempat yang lebih kering sehingga umpan yang berair tidak dikonsumsi maksimal. Talamond dan 


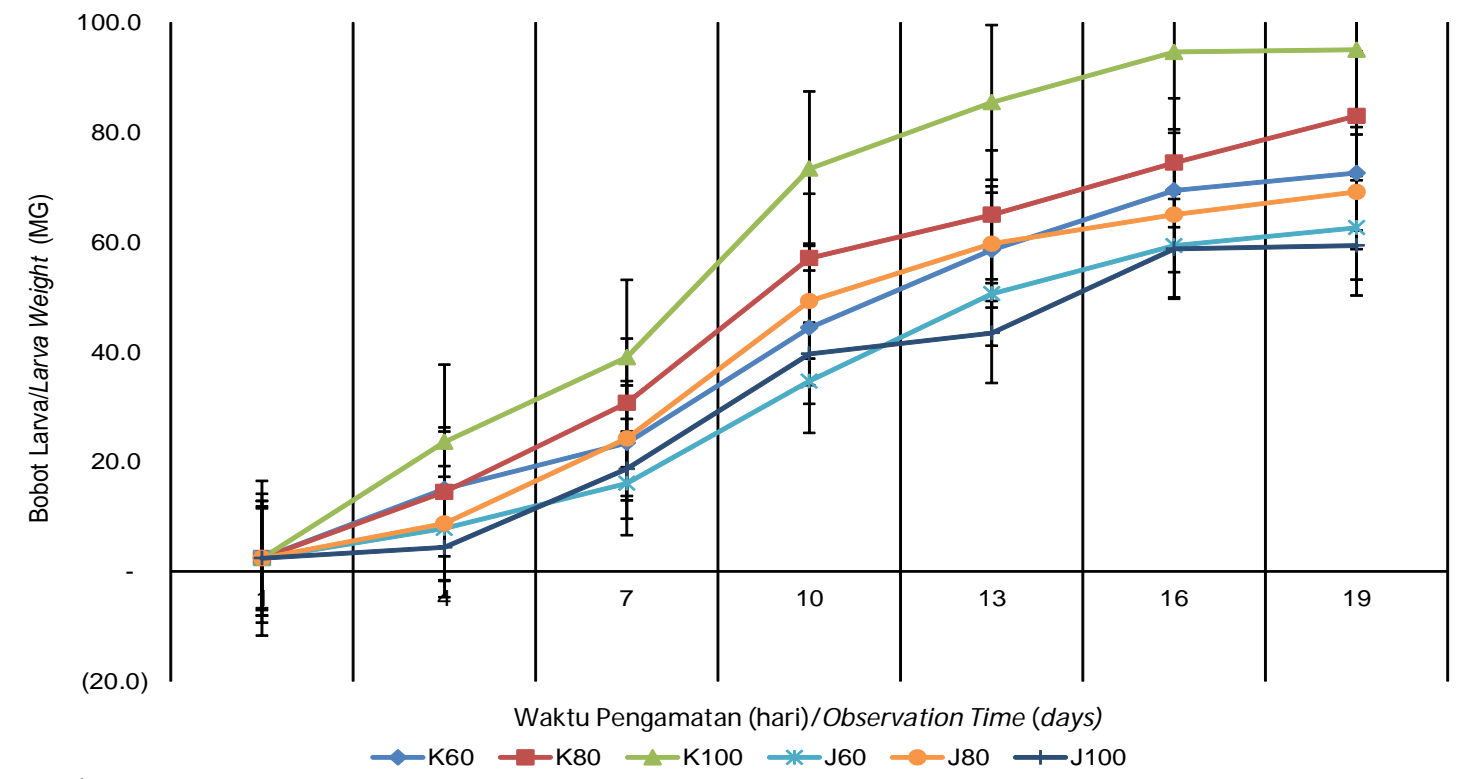

Keterangan/Note:

$\mathrm{K} 60$ = laju umpan kepala tuna $60 \mathrm{mg} / \mathrm{larva} / \mathrm{hari} /$ feeding rates of tuna head $60 \mathrm{mg} / \mathrm{larva} /$ day

$\mathrm{K} 80$ = laju umpan kepala tuna $80 \mathrm{mg} / \mathrm{larva} / \mathrm{hari} /$ feeding rates of tuna head $80 \mathrm{mg} / \mathrm{larva} /$ day

$\mathrm{K} 100$ = laju umpan kepala tuna $100 \mathrm{mg} / \mathrm{larva} / \mathrm{hari} /$ feeding rates of tuna head $100 \mathrm{mg} / \mathrm{larva} /$ day

$\mathrm{J} 60$ = laju umpan jeroan tuna $60 \mathrm{mg} / \mathrm{larva} / \mathrm{hari} /$ feeding rates of tuna viscera $60 \mathrm{mg} / \mathrm{larva} /$ day

$\mathrm{J} 80$ = laju umpan jeroan tuna $80 \mathrm{mg} / \mathrm{larva} / \mathrm{hari} /$ feeding rates of tuna viscera $80 \mathrm{mg} / \mathrm{larva} /$ day

$\mathrm{J} 100$ = laju umpan jeroan tuna $100 \mathrm{mg} / \mathrm{larva} / \mathrm{har} /$ feeding rates of tuna viscera $100 \mathrm{mg} / \mathrm{larva} /$ day

Gambar 3. Bobot larva selama masa pemeliharaan dengan pemberian pakan kepala tuna (K) dan jeroan tuna $(\mathrm{J})$

Figure 3. Weight of larva during cultivation fed with tuna head (K) and viscera (J)

Sukarman (2014) dan Diener et al. (2009) menyatakan bahwa kondisi umpan yang paling optimum untuk pertumbuhan larva BSF adalah dengan kandungan air sebesar $60 \%$. Kemungkinan penyebab perbedaan bobot larva ialah umpan berupa kepala lebih efisien untuk dikonversi menjadi biomassa larva. Hal ini terlihat dari sisa umpan kepala yang lebih sedikit dibandingkan umpan berupa jeroan. Tabel 5 menunjukkan bahwa larva lebih mudah mencerna kepala dibandingkan dengan umpan berupa jeroan

Tabel 5. Jumlah sisa pakan dan yang tercerna terhadap bobot larva Table 5. The amount of feed residue and digested to the larva weight

\begin{tabular}{lcccc}
\hline $\begin{array}{c}\text { Perlakuan/ } \\
\text { Treatments }\end{array}$ & $\begin{array}{c}\text { Total Pakan/Total feed } \\
(\mathbf{g})\end{array}$ & $\begin{array}{c}\text { Total sisa pakan/Feed } \\
\text { residu }(\mathbf{g})\end{array}$ & $\begin{array}{c}\text { Tercerna/ } \\
\text { Digested }(\mathbf{g})\end{array}$ & $\begin{array}{c}\text { Bobot Total larva / } \\
\text { Total of larva } \\
\text { weight }(\mathbf{g})\end{array}$ \\
\hline $\mathrm{K} 60$ & $215.5 \pm 0.8^{\mathrm{c}}$ & $49.4 \pm 2.3^{\mathrm{d}}$ & $151.7 \pm 1.8^{\mathrm{abc}}$ & $14.4 \pm 1.4^{\mathrm{abc}}$ \\
$\mathrm{K} 80$ & $286.9 \pm 0.9^{\mathrm{ab}}$ & $91.1 \pm 15.7^{\mathrm{b}}$ & $179.3 \pm 15.5^{\mathrm{ab}}$ & $16.4 \pm 2.8^{\mathrm{ab}}$ \\
$\mathrm{K} 100$ & $349.3 \pm 15.5^{\mathrm{a}}$ & $125.4 \pm 4.7^{\mathrm{a}}$ & $205.7 \pm 17.0^{\mathrm{a}}$ & $18.1 \pm 3.7^{\mathrm{a}}$ \\
$\mathrm{J} 60$ & $174.2 \pm 28.4^{\mathrm{c}}$ & $64.4 \pm 8.9^{\mathrm{cd}}$ & $99.9 \pm 18.8^{\mathrm{c}}$ & $9.9 \pm 2.9^{\mathrm{cd}}$ \\
$\mathrm{J} 80$ & $219.1 \pm 45.8^{\mathrm{bc}}$ & $85.3 \pm 5.8^{\mathrm{bc}}$ & $123.5 \pm 37.2^{\mathrm{bc}}$ & $10.1 \pm 2.9^{\mathrm{bcd}}$ \\
$\mathrm{J} 100$ & $230.7 \pm 27.5^{\mathrm{bc}}$ & $109.0 \pm 8.0^{\mathrm{ab}}$ & $114.3 \pm 25.6^{\mathrm{c}}$ & $7.4 \pm 1.6^{\mathrm{d}}$ \\
\hline
\end{tabular}

$\mathrm{a}=$ Notasi huruf yang sama dalam kolom yang sama menunjukkan perbedaan nilai tidak signifikan $(\mathrm{p} \geq 0,05) /$ The same letters notation within a column shows no significant difference $(p \geq 0.05)$

Keterangan/Note:

$\mathrm{K} 60$ = laju umpan kepala tuna $60 \mathrm{mg} / \mathrm{larva} / \mathrm{har} /$ feeding rates of tuna head $60 \mathrm{mg} / \mathrm{larva} /$ day

$\mathrm{K} 80$ = laju umpan kepala tuna $80 \mathrm{mg} / \mathrm{larva} / \mathrm{hari} /$ feeding rates of tuna head $80 \mathrm{mg} / \mathrm{larva} /$ day

$\mathrm{K} 100$ = laju umpan kepala tuna $100 \mathrm{mg} / \mathrm{larva} / \mathrm{hari} /$ feeding rates of tuna head $100 \mathrm{mg} / \mathrm{larva} /$ day

$\mathrm{J} 60$ = laju umpan jeroan tuna $60 \mathrm{mg} / \mathrm{larva} / \mathrm{hari} /$ feeding rates of tuna viscera $60 \mathrm{mg} / \mathrm{larva} /$ day

$\mathrm{J} 80$ = laju umpan jeroan tuna $80 \mathrm{mg} / \mathrm{larva} / \mathrm{hari} /$ feeding rates of tuna viscera $80 \mathrm{mg} / \mathrm{larva} /$ day

$\mathrm{J} 100$ = laju umpan jeroan tuna $100 \mathrm{mg} / \mathrm{larva} / \mathrm{hari} /$ feeding rates of tuna viscera $100 \mathrm{mg} / \mathrm{larva} /$ day 
yang diindikasikan sisa umpan berupa jeroan cenderung lebih tinggi dibandingkan perlakuan kepala.

\section{Tingkat kelulusan hidup (survival rate)}

Larva BSF pada penelitian ini memiliki tingkat kelulusan hidup sebesar $41,33-98,33 \%$. Nilai tingkat kelulusan hidup atau survival rates (SR) tertinggi pada perlakuan K60 dengan 192 ekor larva hidup dan terendah pada perlakuan $\mathrm{J} 100$ dengan 83 ekor larva hidup (Gambar 4). Kelompok umpan kepala menghasilkan SR lebih tinggi dibandingkan kelompok umpan berupa jeroan ikan. Berdasarkan analisa statistik perbedaan jumlah umpan dalam satu kelompok pakan tidak berbeda nyata $(p>0.05)$. Kandungan protein yang lebih tinggi dan kadar air umpan yang sesuai menyebabkan larva BSF dengan kelompok umpan kepala memiliki SR lebih baik dibandingkan dengan kelompok umpan jeroan. Hal ini juga ditandai dengan nilai WRI dan ECD yang lebih tinggi (Tabel 4). Pemberian umpan jeroan tuna mempengaruhi pertumbuhan hidup larva BSF.

Kadar air jeroan mempengaruhi SR larva BSF. Hal ini dikemukakan oleh Fatchurochim, Geden, dan Axtell (1989) yang melakukan penelitian terhadap pengaruh kadar air dalam pakan (kotoran ternak) BSF. Hasil penelitian tersebut menunjukkan bahwa larva BSF masih mampu hidup pada pakan yang mengandung kadar air sebesar 20-90\% dengan nilai SR rendah. Sedangkan SR larva tertinggi tercapai pada pakan dengan kadar air 40-60\%.

Data pada Tabel 4 menunjukkan bahwa perbedaan laju umpan untuk larva BSF menyebabkan perbedaan nilai konsumsi umpan antara K60 dengan K100, J60, J80 dan J100. Pola yang sama juga terjadi pada parameter WRI. Namun perbedaan jumlah laju umpan yang dikonsumsi oleh larva tidak berpengaruh pada bobot larva setelah 19 hari masa pemeliharaan. Hal ini berkaitan dengan nilai $E C D$, yaitu dengan perlakuan jumlah umpan yang berbeda nilai ECD yang diperoleh tidak berbeda signifikan sehingga bobot larva cenderung sama. Sedangkan perbedaan jenis umpan menggambarkan pola yang berbeda yaitu larva dengan umpan kepala lebih tinggi bobotnya dibandingkan larva dengan umpan jeroan.

Nilai SR larva juga berkaitan dengan nilai ECD. Nilai ECD yang lebih tinggi menyebabkan larva yang hidup hingga akhir masa pemeliharaan lebih tinggi juga. Larva yang diberi umpan limbah kepala tuna

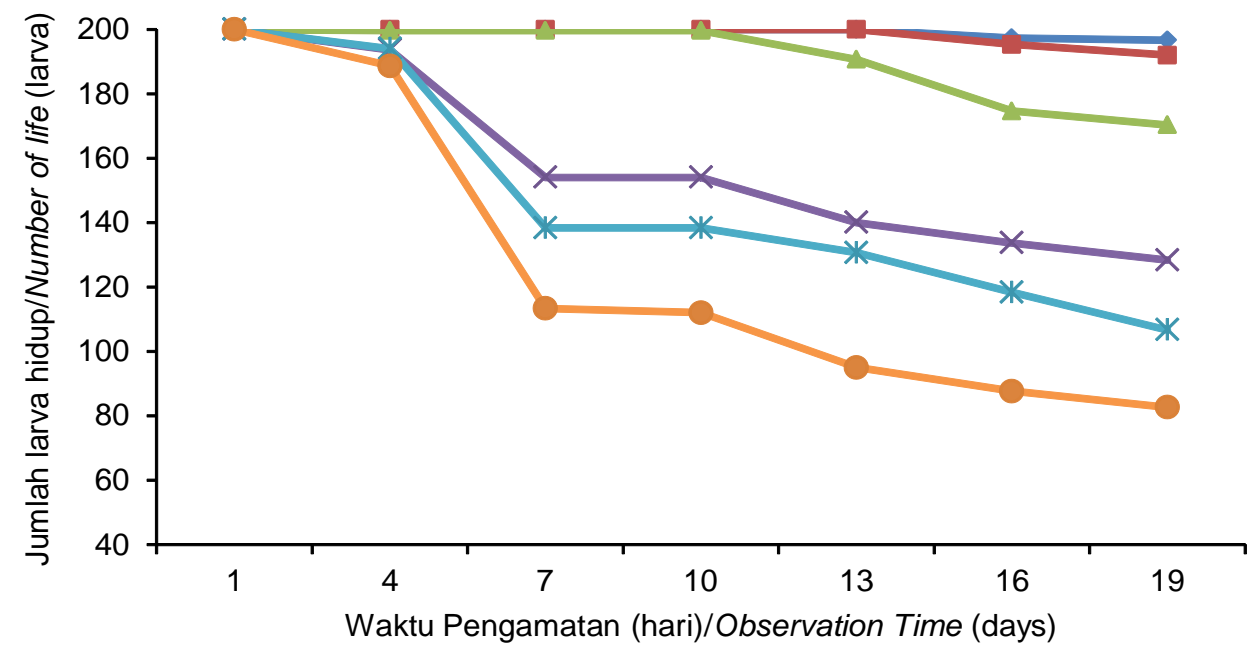

$\leadsto \mathrm{K} 60 \rightarrow \mathrm{K} 80 \rightarrow \mathrm{K} 100 \multimap \mathrm{J} 60 \multimap \mathrm{J} 80 \multimap \mathrm{J} 100$

Keterangan/Note :

$\mathrm{K} 60$ = laju umpan kepala tuna $60 \mathrm{mg} / \mathrm{larva} / \mathrm{hari} /$ feeding rates of tuna head $60 \mathrm{mg} / \mathrm{larva} /$ day

$\mathrm{K} 80$ = laju umpan kepala tuna $80 \mathrm{mg} / \mathrm{larva} / \mathrm{hari} /$ feeding rates of tuna head $80 \mathrm{mg} / \mathrm{larva} /$ day

$\mathrm{K} 100$ = laju umpan kepala tuna $100 \mathrm{mg} / \mathrm{larva} / \mathrm{har} /$ feeding rates of tuna head $100 \mathrm{mg} / \mathrm{larva} /$ day

$\mathrm{J} 60$ = laju umpan jeroan tuna $60 \mathrm{mg} / \mathrm{larva} / \mathrm{hari} /$ feeding rates of tuna viscera $60 \mathrm{mg} / \mathrm{larva} /$ day

$\mathrm{J} 80$ = laju umpan jeroan tuna $80 \mathrm{mg} / \mathrm{larva} / \mathrm{hari} /$ feeding rates of tuna viscera $80 \mathrm{mg} / \mathrm{larva} /$ day

$\mathrm{J} 100$ = laju umpan jeroan tuna $100 \mathrm{mg} / \mathrm{larva} / \mathrm{hari} /$ feeding rates of tuna viscera $100 \mathrm{mg} / \mathrm{larva} /$ day

Gambar 4. Tingkat kelulusan hidup larva BSF

Figure 4. Survival rates of BSF larvae 
memiliki nilai SR lebih tinggi dibandingkan larva yang diberi umpan limbah jeroan tuna.

Berdasarkan data dan uraian di atas maka perlakuan umpan berupa kepala tuna menghasilkan nilai konsumsi umpan, WRI, ECD, bobot dan SR yang lebih tinggi dibandingkan larva yang diberi perlakuan umpan jeroan. Di antara perlakuan umpan kepala (K60, $\mathrm{K} 80, \mathrm{~K} 100$ ), pemberian laju umpan kepala sebesar $60 \mathrm{mg} / \mathrm{larva} / \mathrm{hari}$ akan lebih menguntungkan karena dengan jumlah laju umpan yang lebih sedikit akan mampu menghasilkan konsumsi umpan, WRI, bobot larva, ECD dan SR larva yang sama dengan laju umpan yang lebih banyak (K80 dan K100).

\section{KESIMPULAN}

Limbah kepala dan jeroan tuna dapat digunakan sebagai pakan BSF dengan nilai SR sebesar 41.33 $98.33 \%$. Laju umpan yang menghasilkan proses biokonversi paling optimum adalah umpan berupa kepala tuna sebesar $60 \mathrm{mg} / \mathrm{larva} / \mathrm{hari}$ (K60). Nilai parameter-parameter yang dihasilkan pada perlakuan K60 adalah konsumsi umpan 77,09\%, WRI 4,06\% per hari, ECD 8,32\%, bobot larva 72,59 mg dan SR $98,33 \%$. Jenis limbah tuna berpengaruh terhadap BSF yang dihasilkan. Limbah berupa kepala tuna menghasilkan konsumsi umpan, WRI, ECD bobot larva dan SR yang lebih tinggi dibandingkan limbah jeroan tuna. Penggunaan limbah kepala tuna dapat dimanfaatkan untuk mereduksi limbah sekaligus menghasilkan bahan pakan yang potensial. Kandungan proksimat larva BSF dengan umpan kepala tuna sebesar $60 \mathrm{mg} / \mathrm{larva} /$ hari meliputi protein $25,38 \%$, lemak $6,85 \%$ dan air $62,81 \%$.

\section{DAFTAR PUSTAKA}

Affiano, I. (2011). Analisis perkembangan histamin tuna (Thunnus Sp.) dan bakteri pembentuknya pada beberapa setting standar suhu penyimpanan. Skripsi. Institut Pertanian Bogor. Bogor.

Ahmad, I. (2001). Dietary compensatory feeding in manduca sexta (lepidoptera: sphi ngidae) larvae. Jurnal Perlindungan Tanaman Indonesia, Vol. 7, No. 2, 2001: 81"92.

[AOAC] Association of Official Analytical Chemist. (2006). Official Method of Analysis of Official Analytical of Chemist. The Association of Official Analytical Chemist, Inc. Arlington.

Bappenas. (2014). Kajian Strategi Pengelolaan Perikanan Berkelanjutan. Kementerian PPN / Bappenas Direktorat Kelautan dan Perikanan.

Bonso, N. K. (2013). Bioconversion of organic fraction of solid waste using the larvae of the black soldier fly (Hermetia illucens). Thesis. Departement of Civil Engineering. Kwame Nkrumah University.
Diener, S., Zurbrügg, C., \& Tockner, K. (2009). Conversion of organic material by black soldier fly larvae establishing optimal feeding rates. Waste Management \& Research 27: 603-610. doi: 10.1177/ $07342442 \times 09103838$.

Diener, S., Solano, N. M., Roa Gutiérrez, F., Zurbrugg, C. \& Tockner, K. (2011). Biological treatment of municipal organic waste using black soldier fly larvae. Waste and Biomass Valorization 2: 357-363. doi 10.1007/ s12649-011-9079-1

Dong, S. Z., Chen, Y. F., Huang, Y. H., \& Feng, D. Y. (2009). Research on feed characteristics of Bacillus natto. Chinese J Anim Nutr. 21:371-378

Driemeyer, H. (2016). Evaluation of black soldier fly (Hermetia illucens) larvae as an alternative protein source in pig creep diets in relation to production, blood and manure microbiology parameters. Master Thesis. Faculty of AgriScience at Stellenbosch University

Fahmi, M. R. (2015). Optimalisasi proses biokonversi dengan menggunakan mini-larva Hermetia illucens untuk memenuhi kebutuhan pakan ikan. Pros Sem Nas Masy Biodiv Indon. Volume 1, Nomor 1. Hal 139 -144. doi. 10.13057/psnmbi/m010124

Fahmi, M. R., Hem, S., \& Subamia, I. W. (2009). Potensi Maggot untuk Peningkatan Pertumbuhan dan Status Kesehatan Ikan. Jurnal Riset Akuakultur Vol. 4 No. 2 , 221-232

Fatchurochim, S., Geden, C. J., \& Axtell, R. C. (1989). Filth fly (Diptera) oviposition and larval development in poultry manure of various moisture levels. J. Entomol. Sci. 24 (2), 224-231. doi. 10.18474/07498004-24.2.224

Ghaly, A. E., Ramakrishnan, V. V., Brooks, M. S., Budge, S. M., \& Dave, D. (2013). Fish processing wastes as a potential source of proteins, amino acids and oils: a critical review. J. Microb. Biochem. Technol. 5, 107 - 129. doi: $10.4172 / 1948$ - 5948.1000110

Hartoto, A. N. (2011). Budidaya maggot lalat hitam (Hermetia illucens) pada limbah sayuran sebagai bahan pakan ikan dengan menggunakan pot biokonversi. Tesis. Magister Sistem Teknik. Program Pasca Sarjana. Universitas Gadjah Mada. Yogyakarta Kantun, W., Mallawa, A., \& Rapi, N. L. (2014). Struktur Ukuran dan Jumlah Tangkapan Tuna Madidihang Thunnus albacares Menurut Waktu Penangkapan dan Kedalaman di Perairan Majene Selat Makasar. Jurnal Saintek Perikanan. Vol 9, No 2, Hal 39-48.

Kim, W., Bae, S., Park, K., Lee, S., Choi, Y., Han, S., \& Koh, Y. (2011). Biochemical characterization of digestive enzymes in the black soldier fly, Hermetia illucens (Diptera: Stratiomyidae). Journal of AsiaPasific Entomology 14. 11-14. doi.org/10.1016/ j.aspen.2010.11.003

Li, Q., Zheng, L., Cai, H., Garza, E., Yu, Z., \& Zhou, S. (2011). From organic waste to biodiesel: Black soldier fly, Hermetia illucens, makes it feasible. Journal Fuel 90. 1545-1548. doi.org/10.1016/ j.fuel.2010.11.016

Li, S., Ji, H., Zhang, B., Tian,J., Zhou,J., \& Yu, H. (2016). Influence of black soldier fly (Hermetia illucens) larvae 
oil on growth performance, body composition, tissue fatty acid composition and lipid deposition in juvenile Jian carp (Cyprinus carpio var. Jian). Journal Aquaculture, 465. 43-52. doi.org/10.1016/ j.aquaculture.2016.08.020

Mangunwardoyo, W., Aulia, \& Hem S. (2011). Penggunaan bungkil inti kelapa sawit hasil biokonversi sebagai substrat pertumbuhan larva Hermetia illucens L (maggot). Biota. 16:166-172. doi.org/10.24002/biota.v16i2.95

Mutafela, R. N. (2015). High value organic waste treatment via black soldier fly bioconversion. Master of Science Thesis. Royal Institute of Technology. Stockholm

Myers, H. M., Tomberlin, J. K., Lambert, B. D., \& Kattes, D. (2008). Development of black soldier fly (Diptera: Stratiomyidae) larvae fed dairy manure. Environmental Entomology, 37, 11-15.

Newton, L., Sheppard, C., Watson, D. W., Burtle, G., \& Dove, R. (2005). Using the black soldier fly, Hermetia illucens, as a value- added tool for the management of swine manure. Report for The Animal and Poultry waste Management Center. North Carolina State University Raleigh.

Nguyen, T. T., Tomberlin, J. K., \& Vanlaerhoven, S. (2015). Ability of Black Soldier Fly (Diptera: Stratiomyidae) Larvae to Recycle Food Waste. Environ. Entomol. 15. doi: $10.1093 /$ ee/nvv002

Nurhayati, T., Salamah, E., Cholifah, \& Nugraha, R. (2014). Optimasi proses pembuatan hidrolisat jeroan ikan kakap putih. JPHPI, 17(1).

Peranginangin, R., Agusman, \& Poernomo, A. (2011). Penelitian dan Pengembangan Pengolahan Hasil Samping Industri Perikanan. Analisis Kebijakan. Pengembangan Industri Pengolahan Hasil Perikanan dan Kelautan. Balitbang. KKP.

Riyanto, B., Uju., \& Halimi, S. (2012). Recovery enzim protease dari jeroan ikan tuna dengan teknologi ultrafiltrasi dan reverse osmosis. JPHPI, 15 (2). doi.org/10.17844/jphpi.v15i2.6184

Rachmawati., Buchori, D., Hidayat, P., Hem, S., \& Fahmi, M. R. (2010). Perkembangan dan Kandungan Nutrisi Larva Hermetia illucens (Linnaeus) (Diptera: Stratiomyidae) pada Bungkil Kelapa Sawit. J. Entomol. Indon., 7(1), 28-41 28.

Retnowati, N. (2011). Kebijakan pemanfaatan limbah hasil perikanan. Disampaikan pada Focus Group Discussion "mengubah limbah perikanan menjadi hasil samping yang bernilai tambah". Balai Besar Penelitian dan Pengembangan Pengolahan Produk dan Bioteknologi Kelautan dan Perikanan. Jakarta. 5 oktober 2011

Saragi, E. S., \& Bagastyo, A. Y. (2015). Reduction of organic solid waste by black soldier fly (Hermetia illucens) larvae. The 5th Environmental Technology and Management Conference "Green Technology towards Sustainable Environment" November 23 24, 2015, Bandung, Indonesia.

Scriber, J. M., \& Slansky, F. (1981). Selected bibliography and summary of quantitative food utilization by immature insects. Bulletin of the Entomological Society of America, 28, 43-55.

Sheppard, D. C., Newton, G. L., Thompson, S. A., \& Savage, S. (1994). A value-added manure management-system using the black soldier fly. Bioresource Technology, 50, 275-279. doi.org/ 10.1016/0960-8524(94)90102-3

Simpson, S. J., \& Simpson, C. L. (1990). The mechanism of nutritional compensation by phytophagus insect. Pp. 111-160. In: Insect-plant interaction. 2. CRC press, Florida.

Supriyatna, A., Manurung, R., Esyanti, R. R ., \& Putra, R. E. (2016). Growth of black soldier larvae fed on cassava peel wastes, An agriculture waste. Journal of Entomology and Zoology Studies, 4(6), 161-165.

Talamond, P., \& Sukarman. (2013). Substrates for Rearing. In Caruso, D., Devic, E., Subamia, I.W., Talamond, P., Baras, E (Ed.). Technical handbook of domestication and production of diptera Black Soldier Fly (BSF) Hermetia illucens, Stratiomyidae. (pp 11 20). PT Penerbit IPB Press.Kampus IPB Taman Kencana Bogor.

Timmins, W. K., Bellward, A. J., Stamp, J., \& Reynolds, S. J. (1988). Food Intake, Conversion Efficiency, and Feeding Behaviour of Tobacco Hornworm Caterpillars Given Artificial Diet of Varying Nutrient and Water Content. Physiol. Ent. 13, 303-314. doi:10.1111/ j.1365-3032.1988.tb00482.x

Tomberlin, J. K., Sheppard, D. C., \& Joyce, J.A. (2002). Selected life-history traits of Black Soldier Flies (Diptera: Stratiomyidae) reared on three artificial diets. Ann Entomol Soc Am. 95:379-386. doi. org/10.1603/ 0013-8746(2002)095[0379:SLHTOB]2.0.CO;2.

Tran, G. Gnaedinger, C., \& Melin, C. (2014). Black soldier fly larvae (Hermetia illucens). Feedipedia. Org. Melalui: http://www.feedipedia.org/node.16388.

Trilaksani, W. (2011). Isu terkini dan inovasi teknologi pemanfaatan limbah perikanan. Disampaikan pada Focus Group Discussion "mengubah limbah perikanan menjadi hasil samping yang bernilai tambah". Balai Besar Penelitian dan Pengembangan Pengolahan Produk dan Bioteknologi Kelautan dan Perikanan. Jakarta. 5 oktober 2011

Tschirner, M., \& Simon, A. (2015). Influence of different growing substrates and processing on the nutrient composition of black soldier fly larvae destined for animal feed. Journal of Insects as Food and Feed, 1(4), 249-259. doi.org/10.3920/JIFF2014.0008.

Wardhana, A. H., (2016). Black soldier fly (Hermetia illucens) sebagai sumber protein alternatif untuk pakan ternak. Wartazoa, vol 26, No. 2. Hal 69-78. doi.org/10.14334/wartazoa.v26i2.1218

Widodo, M. S., \& Fakhri, M. (2015). Pemanfaatan pakan organik pada budidaya lele dumbo (Clarias gariepinus) di Kabupaten Probolinggo. Journal of Innovation and Applied Technology. 1(2), 159 - 163.

Yu, G., Cheng, P., Chen, Y., Li, Y., Yang, Z., Chen, Y., \& Tomberlin, J. K. (2011). Inoculating poultry manure with companion bacteria influences growth and 
development of Black Soldier Fly (Diptera: Stratiomyidae) larvae. Environ Entomol. 40, 30-35. doi: 10.1603/EN10126.

Zheng, L., Li, Q., Zhang, J., \& Yu, Z. (2012). Double the biodiesel yield: rearing black soldier fly larvae,
Hermetia illucens, on solid residual fraction of restaurant waste after grease extraction for biodiesel production. Renewable Energy, 41, 75-79. doi.org/ 10.1016/j.renene.2011.10.004 
JPB Kelautan dan Perikanan Vol. 12 No. 2 Tahun 2017: 179-192 